\title{
Change in groundwater conditions as a cause of structural failure - selected case studies
}

\author{
Tomasz Godlewski ${ }^{1, *}$, Witold Bogusz ${ }^{1}$ and Lukasz Kaczyński ${ }^{1}$ \\ ${ }^{1}$ Instytut Techniki Budowlanej, ul. Ksawerów 21, 02-775 Warszawa, Polska
}

\begin{abstract}
The paper presents the summary of five case studies related to structural failures that were caused by the change in groundwater conditions during the existence of the buildings. The failures resulted from excessive differential settlements that were caused either by reactivation of consolidation process, due to change in effective stresses, or a change in water content in the case of expansive soils.
\end{abstract}

\section{Introduction}

The main causes of geotechnical failures, which are related to changes in groundwater conditions, include [1]: leakage of water mains and sewage systems, lowering of groundwater table, as well as water-induced shrinkage and swelling of expansive soils. Those types of failures comprise approximately $25-30 \%$ of all recorded cases.

Failures that can be traced back to leaking water pipes and sewage systems are incidental and hard to foresee due to their random nature. However, in most cases, they can be relatively easily repaired by the removal of the original cause (repair of the faulty utilities). The other causes are related mainly to ground conditions and soil characteristics, and may have cyclic and long-term effects. The remediation measures are usually rather complicated and often only temporary in the case of existing structures. Although the potential for occurrence of failure can be assessed at the stage of geotechnical investigation with relative ease, the assessment of probability of failure is difficult due to the complexity of involved phenomena and the variability of influencing factors. However, conducting risk assessment associated with them, as practical experience proves, is not only possible but also necessary.

The paper presents selected case studies of structural failures, which causes could be traced back to the changes in groundwater conditions, occurring during the use of the structures. These cases, based on the description of underlying conditions and soil characteristics, provide a reference, as a lesson learnt, of potential problems to be considered when planning new investments.

\footnotetext{
${ }^{*}$ Corresponding author: t.godlewski@itb.pl
} 


\section{Groundwater related phenomena}

In the case of groundwater lowering, the changes can occur naturally or due to human activities. The former can be related to seasonal variations or be a result of the climate change (long-term trends). They are also related to the level of urbanization of the area, which may affect its hydrological cycle. On the other hand, human activities can include dewatering works (e.g. for deep excavations). Generally, natural processes are more difficult to predict and assess in a given time period (Fig. 1), which is often the design life of the structure.

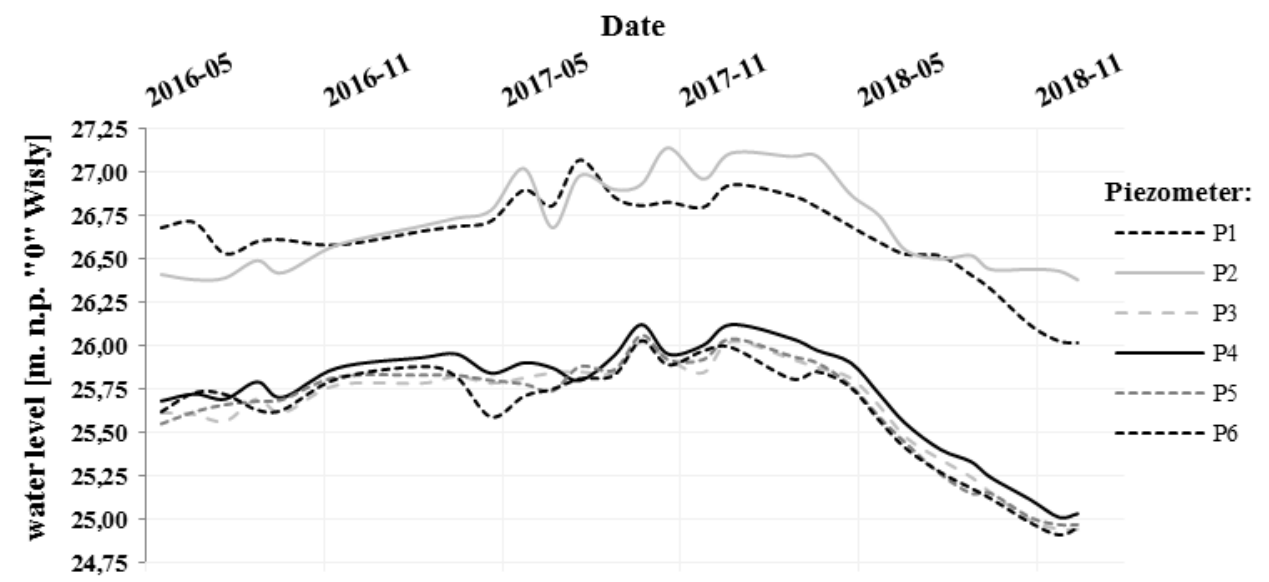

Fig. 1. An example of groundwater lowering in Wola district area in Warsaw, as registered in piezometers.

In such a case, long-term dry periods can lead to lowering of groundwater table, resulting in volumetric changes in the subsoil, as well as the increase of effective stresses. The experiences of ITB show that lowering of $1 \mathrm{~m}$ can result in 1-3 mm of additional settlements in the case of permeable cohesionless soils. In the case of fine-grained (cohesive) soils, this effect can be more pronounced and reactivate consolidation processes. This often results in additional settlements after a period of stabilisation. Their exact values are dependent on the type of the soil and its susceptibility to water content change. The largest settlements are usually observed in the case of organic soils and can reach few centimetres. The reactivated consolidation process usually has the characteristic of long term settlement, which may be similar to settlement caused by creep, as it may show similar trend. As presented case studies show, in the case of expansive soils, the shrinkage and expansion of the soil may play important role in influencing foundation movements. All those phenomena are strongly interrelated as groundwater lowering, in the case of shallowly occurring expansive soils, lead to the change in water content as well [2]. Neogene clays (tertiary Pliocene clays), in the Warsaw area, may exhibit linear shrinkage of up to $10-15 \%$. When water-content change occurs in upper part of those strata (e.g. approx. $0,5 \mathrm{~m}$ ), this may lead to a settlement of more than $5 \mathrm{~cm}$. For typical structures, such values are significant for both serviceability and ultimate limit state consideration. 


\section{Selected case studies}

Presented below are some selected case studies related to failures caused by reactivation of consolidation processes due to natural groundwater changes in the presence of organic soils (case I and II), as well as some cases related to occurrence of expansive soils (case III, IV and V). All presented cases consider existing buildings, in most of which, no damage was observed before the changes in groundwater or the earlier settlements were already stabilized.

\subsection{Case I}

The case regards a gym building which was partially founded on organic soils. This building is a part of a school complex located in Warsaw. It is a typical building used for sport activities, with dimensions of $42 \times 23.5 \mathrm{~m}$. It has been constructed as a light framed structure with primary load-bearing elements composed of reinforced concrete columns with steel roof girders, spaced at the interval of $6 \mathrm{~m}$. Longitudinal external walls are not a part of the main load bearing system. At the north and south side of the building, the gable walls were constructed from two layers of autoclaved aerated concrete blocks covered with plaster. Besides functioning as a curtain, these walls increase the rigidity of the structure and transfer small part of the load from the roof. The foundations of the structure were constructed as cast-in-place footings with dimensions of $1.7 \times 2.0 \mathrm{~m}$ and $2.2 \times 3.0 \mathrm{~m}$, connected by a strip foundation with width of 0.45 and $0.60 \mathrm{~m}$. Northern and southern gable walls were founded on $0.70 \mathrm{~m}$ wide strip foundations.

Generally, the subsoil is composed of fine to coarse alluvial sands with addition of some gravel. However, in the eastern part of the considered area, a layer of organic and soft soils was encountered, of up to $2.5 \mathrm{~m}$ thickness. At the design phase, due to implemented ground investigation methods (e.g. boreholes without casing), these soils were incorrectly identified and described, which lead to the overestimation of their geotechnical parameters. The first groundwater table at that time stabilized at $2 \mathrm{~m}$ below ground level (bgl).

First damage to the structure was recorded after 7 years of use of the building. After next 4 years, new cracks and propagation of existing ones had been noticed. Main cracks were vertical and diagonal, inclined in the eastern direction, ending at half of the height of the southern wall, extending through its entire thickness (Fig. 2).

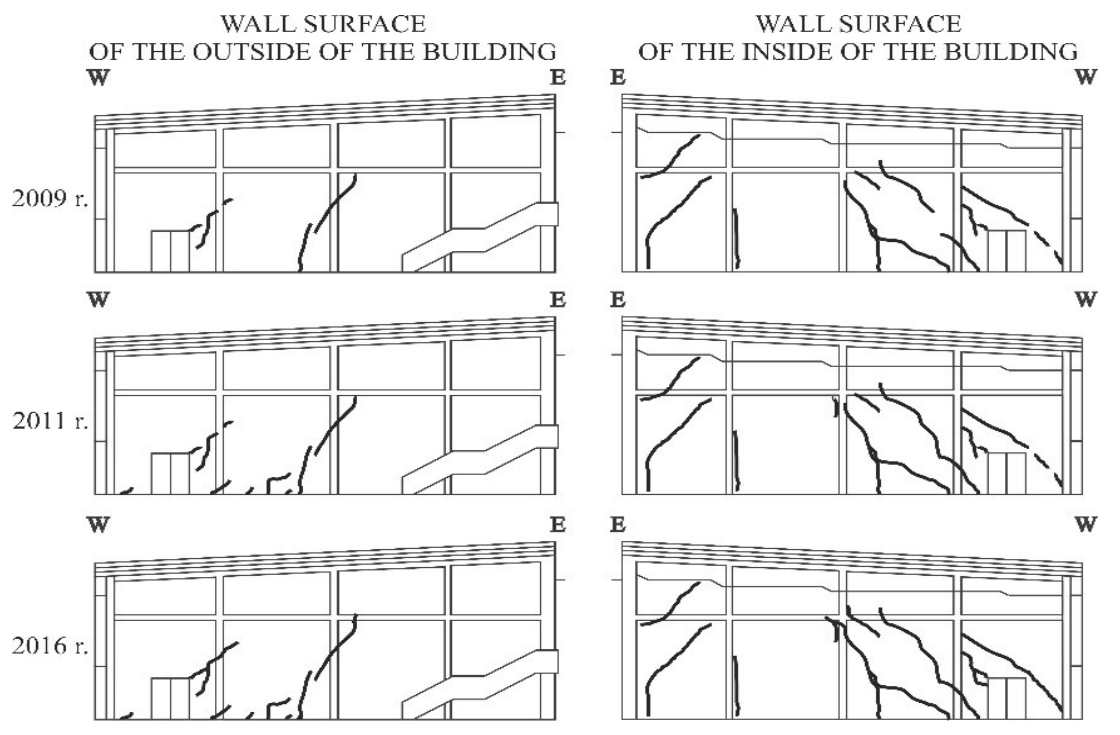


Fig. 2. Evolution of cracks at the southern wall of the building.

The distribution of the cracks and their propagation indicate an ongoing process of degradation. The maximum crack width at the lower part of the wall reached up to $1 \mathrm{~cm}$. Due to this and the general state of the wall, it was considered as a state preceding the failure. The levelling pins were installed on the southern wall to measure its settlement and crack-meters were installed to monitor the progress of cracks.

Recent observations and geotechnical site investigation confirmed earlier conclusions regarding the cause of the damage to the external walls, namely, differential settlements. Conducted analysis showed that foundation on sand layer would result in settlements not exceeding $4 \mathrm{~mm}$. However, on soft soil, the final settlement was predicted at $31 \mathrm{~mm}$. Interestingly, the observed displacement was not characterised by a constant rate of settlement usually observed in such conditions up to stabilisation (typically 1-2 mm/year). More dynamic process has been observed (Fig. 3).

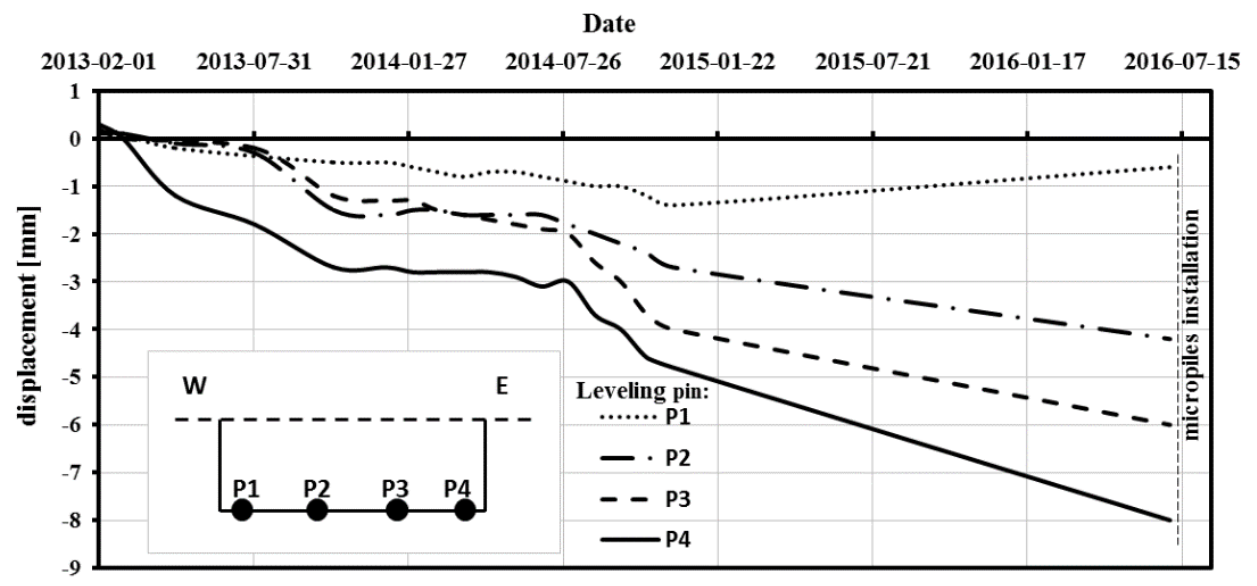

Fig. 3. Vertical displacements of the wall.

Although the data from the time of construction were not available, a clear stabilisation period can be noticed. However, in mid-2014, in relatively short time, a rapid increase in displacements had occurred, by approx. $50 \%$ of the already reached values. The lowering of water table, observed in a relatively large area of Warsaw, was identified as the underlying cause of this behaviour. Those changes were not season-related, but they were probably connected to the changes in hydrological circulation (e.g. decrease of infiltration due to paved areas) rather than associated only with climate change.

Finally, identification of the underlying causes and conducted observations allowed to implement proper remediation measures. Steel micropiles have been installed to support the wall on the bearing stratum. The detailed description of the implemented technology can be found in the earlier publication [3].

\subsection{Case II}

Similar case occurred in Warsaw, where geological formation called "Żoliborz trough" ("Rynna Żoliborska") exists. It is a leftover of ancient lake, from interglacial period, with organic and mineral sediments (i.e. chalk, gytia, peats, silts). These sediments spread through a large area of Warsaw, from southern part near Okęcie area up to Żoliborz district in the north, branching out in different directions, and being responsible for common occurrence of difficult ground conditions for foundation of buildings and other structures in Warsaw. 
Out of the soil types encountered in that area, especially peats and silts are the most problematic, as they occur at shallow depths (3-5 m bgl) and are susceptible to the changes of groundwater level.

Two analysed residential buildings have dimensions of $20.4 \times 22.2 \mathrm{~m}$ and the height of $47 \mathrm{~m}, 17$ storeys high with one underground level. They were constructed in 1970s, founded on a $80 \mathrm{~cm}$ thick foundation slab, $24.6 \times 26.3 \mathrm{~m}$, at a depth of approx. $4.7 \mathrm{~m} \mathrm{bgl}$. The underground part was designed as cast-in-place with bidirectional distribution of walls, ensuring sufficient stiffness and load redistribution. Both buildings were located at the edge of the Żoliborz trough. Directly under their foundations, fine and silty sands are present. Underneath them, a layer of peats is located. Its thickness varies, between 2-3 meters under southern parts of both buildings, and decreasing to their northern parts. Deeper under the foundation, gytias are present, 3 to $7 \mathrm{~m}$ in thickness, as well as $2 \mathrm{~m}$ of fine and silty sands. Underneath those strata, glacial tills and sands, which are typical for entire Warsaw area, exist. First groundwater table was encountered $1 \mathrm{~m}$ below the foundation level in the layer of sand.

Considered buildings have been subjected to extensive settlement practically from the time of their construction. Thanks to the significant rigidity of the foundation and the structure, significant differential settlement resulted only in tilting, in the direction of increasing thickness of soft strata, without significant damage to load bearing structural elements. The investigation and analysis conducted so far, proved that the differential settlement has been a result of the presence of soft strata. Based on this estimation, in 1997, underpinning of the foundation slab, with the use of 8-10 m long jet-grouting columns, was conducted. This action aimed to slow down the process of settlement and reduce its final value, therefore, limiting the tilt of the buildings. As measurements (Fig. 4) show, this action lead to expected reduction of settlements.

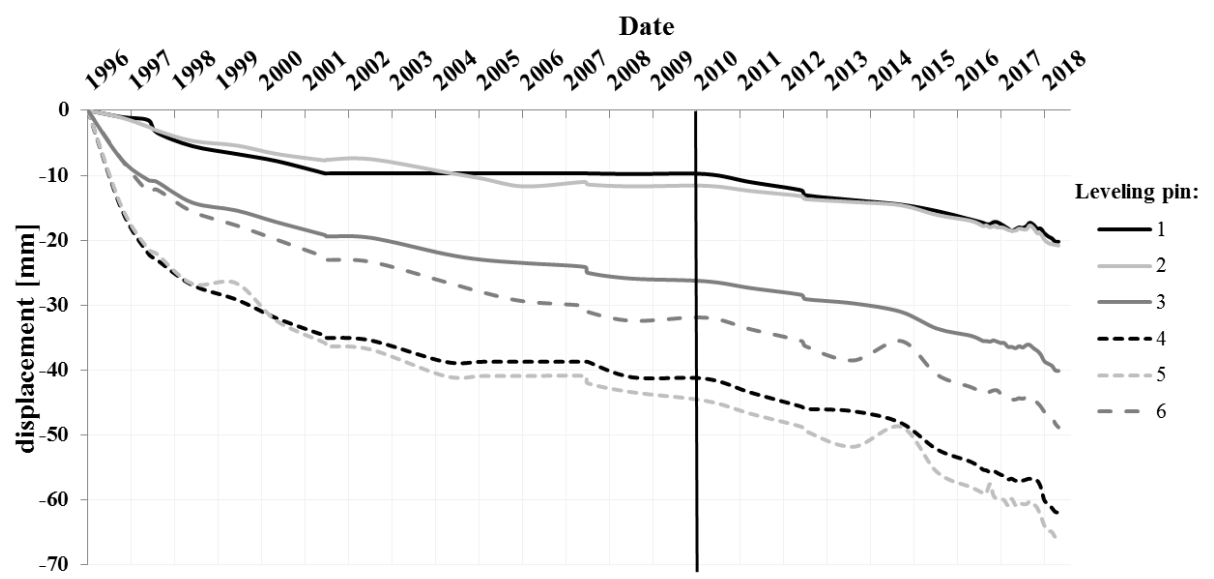

Fig. 4. Displacements of the one of the buildings (after underpinning).

Measured settlements were noticeably stabilizing from the execution of underpinning and displacements after further consolidation reached approx. 5-10 mm. However, from 2010, the displacements increased and the rate of settlement practically doubled. The analysis of groundwater levels, based on piezometer measurements, with additional analysis of regional settlement data obtained from satellite interferometry, lead to the conclusion that reactivation of consolidation processes influenced the behaviour of the buildings. Lowering or even disappearance of the first water table resulted in further consolidation of the peat layer. Although the buildings do not show any signs of reaching ultimate limit state and loss of bearing capacity, excessive tilt may limit serviceability of the structure (e.g. use of elevators). 


\subsection{Case 3}

This case study is related to the presence of expansive soils in relation to long-term cyclic moisture content changes in the subsoil. This example is quite unique, as it concerns the structural failure of the part of the building which was founded on Pliocene clay erratic (material brought in from another area by a glacier). Additionally, the damage that occurred was caused by volumetric changes (shrinkage and expansion) of expansive soil due to changes in moisture content, influenced by neighbouring trees.

The existence of erratics is related to significant glacitectonic distortions of the subsoil. In this case, the older Neogene tertiary clay was separated, transported and deposited by the glacier in quaternary deposits. Such formations usually take form of layers of varying extent and thickness, from centimetres up to dozens of meters. The occurrence of clay erratics at shallow depth usually is a significant geotechnical problem. They are difficult to investigate and document in standard geotechnical documentations as they may be misinterpreted based on limited number of boreholes.

The analysed case is related to a residential building located in Warsaw, 4 storeys high with an underground level. The dimensions of the building are $21.4 \times 14.4 \mathrm{~m}$. It has masonry walls and Klein-type ceilings. The foundation level is at $2.0 \mathrm{~m} \mathrm{bgl}$. The damage to the building presented itself as cracks of varying width. Earlier assessments of the building were related to natural degradation, damage from the war period, thermal influences due to a fire, as well as for the purpose of adding another level to the building. As similar damage was not observed on neighbouring structures, a detailed geotechnical investigation was conducted. It allowed to document the presence of clay erratic, with maximum thickness of $3.5 \mathrm{~m}$, about $1.5 \mathrm{~m}$ below the foundation level (Fig. 5).
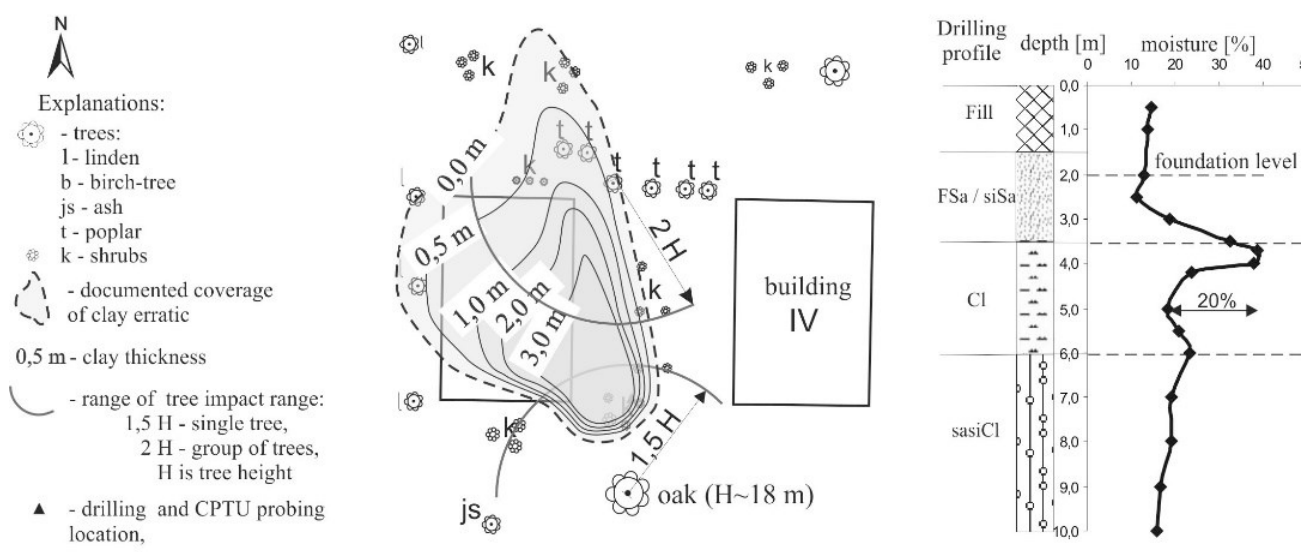

Fig. 5. Situation plan with the extent and thickness of clay erratic, with the range of influence of adjacent trees, as well as measured change of water content in soils samples from various depths.

In addition, the water level originally occurring approx. $2.5 \mathrm{~m}$ bgl was not encountered. However, variations in moisture content of about $20 \%$ were documented in the clay. During investigation, in clay samples, parts of tree roots were noticed, which pointed to the cause of moisture change. The influence of trees, established according to ITB recommendations [4], extended below the building where clay erratic was documented. With limited infiltration due to pavement of the area and drainage, the cause of building settlement was identified as shrinkage of expansive soils. Unfortunately, displacement monitoring was not conducted for this building, but based on available materials, it was estimated that significant damage occurred in the period from 1990 to 2004 . The original $3 \mathrm{~mm}$ cracks increased to $8-12 \mathrm{~mm}$. 
Beside the repair of damage to the walls, the proposed solution was to underpin the building with micropiles extending below the clay erratic. Additionally, changes in upkeep of the trees were proposed, by installation of an irrigation system or removal of the existing trees and their replacement with less invasive species at a safe distance from the building. More details on this case study can be found in [5].

\subsection{Case 4}

Another, very similar case, concerns a historical building located in the central part of Warsaw, near the slope of Vistula river valley. In this case, the underlying causes were also identified as occurrence of expansive soils (clays), close proximity of trees, as well as lack of proper management of rainfall water.

The conducted technical assessment [6] concerned the historical palace complex constructed in 1865 . The $\mathrm{H}$-shaped building has 3 levels above ground and a basement floor. Typical structural elements were used for its construction, including masonry walls and steelceramic ceilings (Klein-type). The strip foundation was placed at the level of $3 \mathrm{~m}$ bgl. The area around the building was paved (pavements and a parking lot). It had been documented that an occlusion of the sewage system constructed around the building lead to leakage. Moreover, the rainfall water was discharged at the area adjacent to the building.

Observed damage and cracks were noticed in north-eastern wing of the building, adjacent to the park area. The first cracks were noticed in 1999, with their progress afterwards. The type of damage suggested the settlement of the entire wing of the building as the cause. The cracks were increasing in width with height, reaching up to $1.5 \mathrm{~cm}$ at the top of the building, with only few millimetres at the ground level.

The analysis of archival geological documentations for this part of Warsaw showed the existence of Pleistocene clays in the subsoil, which were taken upward by glaciation processes. These soils are present underneath a large part of the building. Above the clay layer, in man-made grounds, no water table was encountered. However, in clays under the foundations, high moisture content (25-30\%) was noticed, with a decrease to approx. $16 \%$ at the depth of $5 \mathrm{~m} \mathrm{bgl}$. Similar difference was noticed between soil samples taken from different sides of the building.

The existing cracks and their progression suggested that they were caused by local differential settlement due to the change in moisture content in clays. This hypothesis was further supported by the presence of clays under the foundations of considered part of the building as well as the close proximity of trees. The zone of influence (Fig. 6) of trees was estimated based on [4], in relation to their height.

The estimated zones were noticeably extending under the part of the building. In trial pits near the foundations, tree roots were encountered (Fig. 6), which spread even under the foundation itself. At the same time, no damage has been observed in other parts of the building, even in close proximity to trees but with clay layer at larger depth. Finally, it was judged that cyclic movements (heave and settlement) lead to the occurrence of damage, due to ineffective water management, existing trees, and presence of expansive soils. 

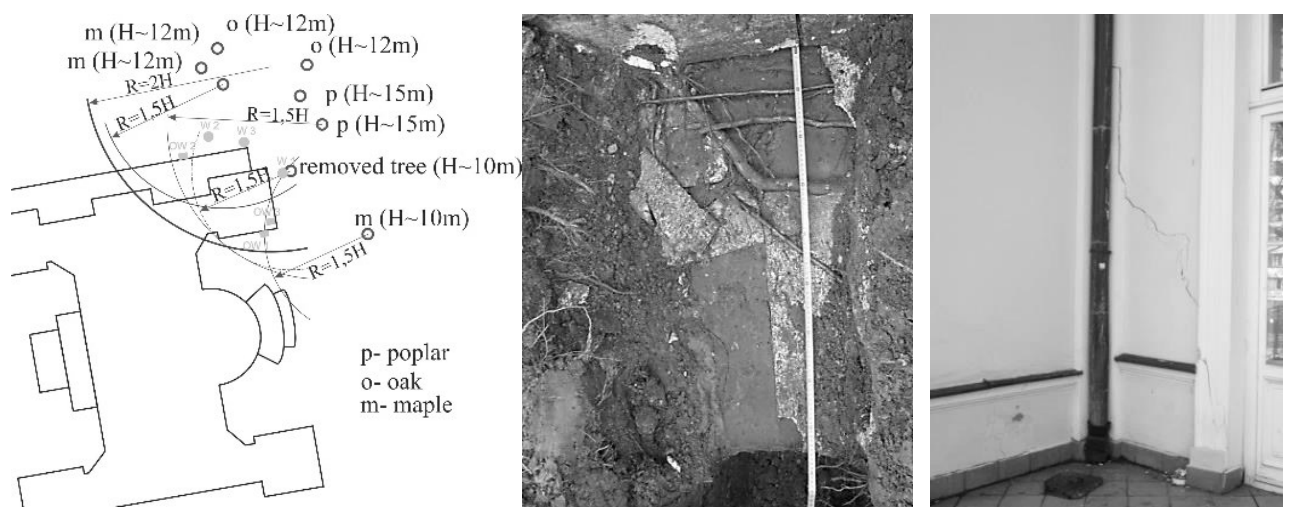

Fig. 6. The extent of influence of trees on the building, the view on tree roots in the trial pit at the north-east side of the building, and the crack at the wall due to resulting differential settlements.

\subsection{Case 5}

The lase case study presents a three storey high residential building located in Mokotów district of Warsaw, near the Vistula river valley. The building was constructed in 1950s and composes of two parts (A and B), resulting in L-shape layout. It was founded on strip foundations at a depth of approx. $2.1 \mathrm{~m} \mathrm{bgl}$ in alluvial soils, above Neogene clays. In the proximity of north-eastern corner, the upper surface of clay strata is located only approx. 0.5-0.7 $\mathrm{m}$ below the foundation.

First damage to the building was recorded in 1970s, with the intensification in 2005-2006. Conducted technical assessment proved the existence of cracks on external walls, mostly in north-eastern corner, reaching through the entire thickness of the walls and with width of up to $5 \mathrm{~mm}$. The cause was identified as shallow occurrence of expansive soils. In 2007, partial underpinning of this part of the building was executed with the use of 11 driven micropiles (140 $\mathrm{mm}$ in diameter, $6.5-7.5 \mathrm{~m}$ in length). Measurements taken later showed that the settlement process stabilised (Fig. 7).

Unfortunately, due to economic constraints, not all necessary works were conducted to remediate the problem (underpinning, repair and monitoring of the whole building). Currently, the process of degradation progresses in other parts of the building. The initial assessment and investigation confirmed the lack of water above the clay stratum.

Strip foundations are not sufficient for limiting the impact of differential settlement on the structure due to the presence of expansive clays. Spread foundations with possible seasonal water table variations lead to further differential displacements. Lack of comprehensive approach to repairs since 1972 resulted in widening of existing cracks and occurrence of new ones. 


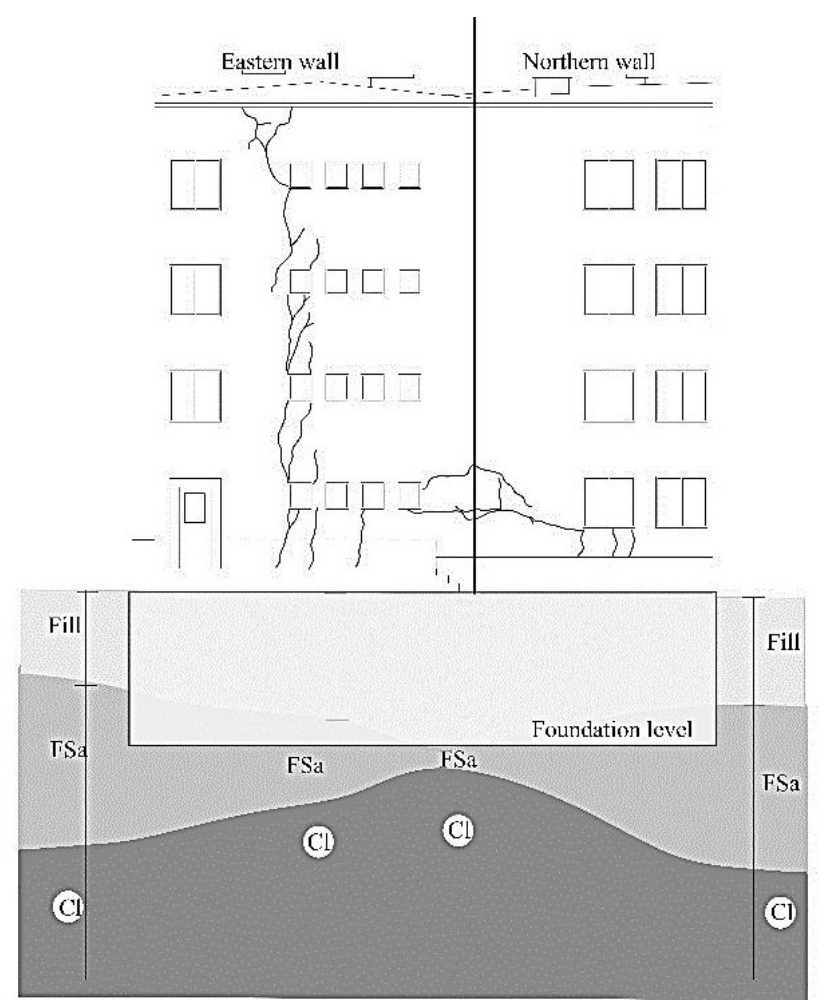

Fig. 7. Damage to north-east corner of the building in the light of geotechnical conditions.

\section{Conclusions}

Presented case studies of structural failures are related to phenomena which may occur under specific conditions, however, always in relation to the changes in groundwater conditions. These changes may be either regional, due to climate change, or local, due to urbanization and the use of neighbouring areas. Although there is not much that can be done with those factors at the design stage, the possibility of their occurrence during the use of the structure should be considered, with the prediction of possible effects on serviceability and stability of the structure. It should be a required consideration in case of encountering soils susceptible to groundwater change (organic and expansive soils) or specific geomorphological situations in relation to hydrological cycle (e.g. water levels in river valleys, on slopes). Such assessment requires estimation of water table variations based on previous data. This is often disregarded in most typical site investigation reports.

In practice, design assumptions should account not only for the situation during the documentation stage and execution, but also for long-term behaviour. The cost of adapting the foundation design to account for difficult ground conditions (organic or expansive soils), through increasing the stiffness of the structure or using deep foundations, will be relatively low in comparison to the possible repairs, which are often technically limited due to existence and use of the structure. In order to identify the risks and make an informed decision, a proper geotechnical investigation should be conducted, of sufficient scope and quality [7]. 


\section{References}

1. M. Tarnawski, Geotechniczne przyczyny awarii budowlanych (ZAPOL, Szczecin, 2011)

2. M. Kumor, Wybrane problemy identyfikacji przemieszczeń fundamentów na podtożu ekspansywnym (Instytut Techniki Budowlanej, Warszawa, 2004) [in Polish]

3. W. Bogusz, T. Godlewski, Ł. Kaczyński, Awaria i zabezpieczenie konstrukcji budynku sali gimnastycznej z wykorzystaniem technologii mikropali (Proceedings of XXVIII Scientific-Technical Conference on Structural Failures, Szczecin-Międzyzdroje, pp. 491-502, 2017) [in Polish]

4. Guideline: L. Wysokiński, Instrukcja nr 296. Posadowienie budowli na gruntach ekspansywnych (Instytut Techniki Budowlanej,Warszawa, 1990) [in Polish]

5. T. Godlewski, Porwak iłów jako przyczyna zniszczenia konstrukcji budynku (Proceedings of XXII Scientific-Technical Conference on Structural Failures, SzczecinMiędzyzdroje, pp. 537-544, 2005) [in Polish]

6. Internal ITB documentation from various expert opinions [in Polish]

7. E. Koda, T. Godlewski, Zasady wykonywania ekspertyz geotechnicznych z uwzględnieniem budynków w zabudowie miejskiej (Proceedings of XV Konferencja Naukowo-Techniczna Warsztat Pracy Rzeczoznawcy Budowlanego, pp. 81-108, Cedzyna, 2018) [in Polish] 